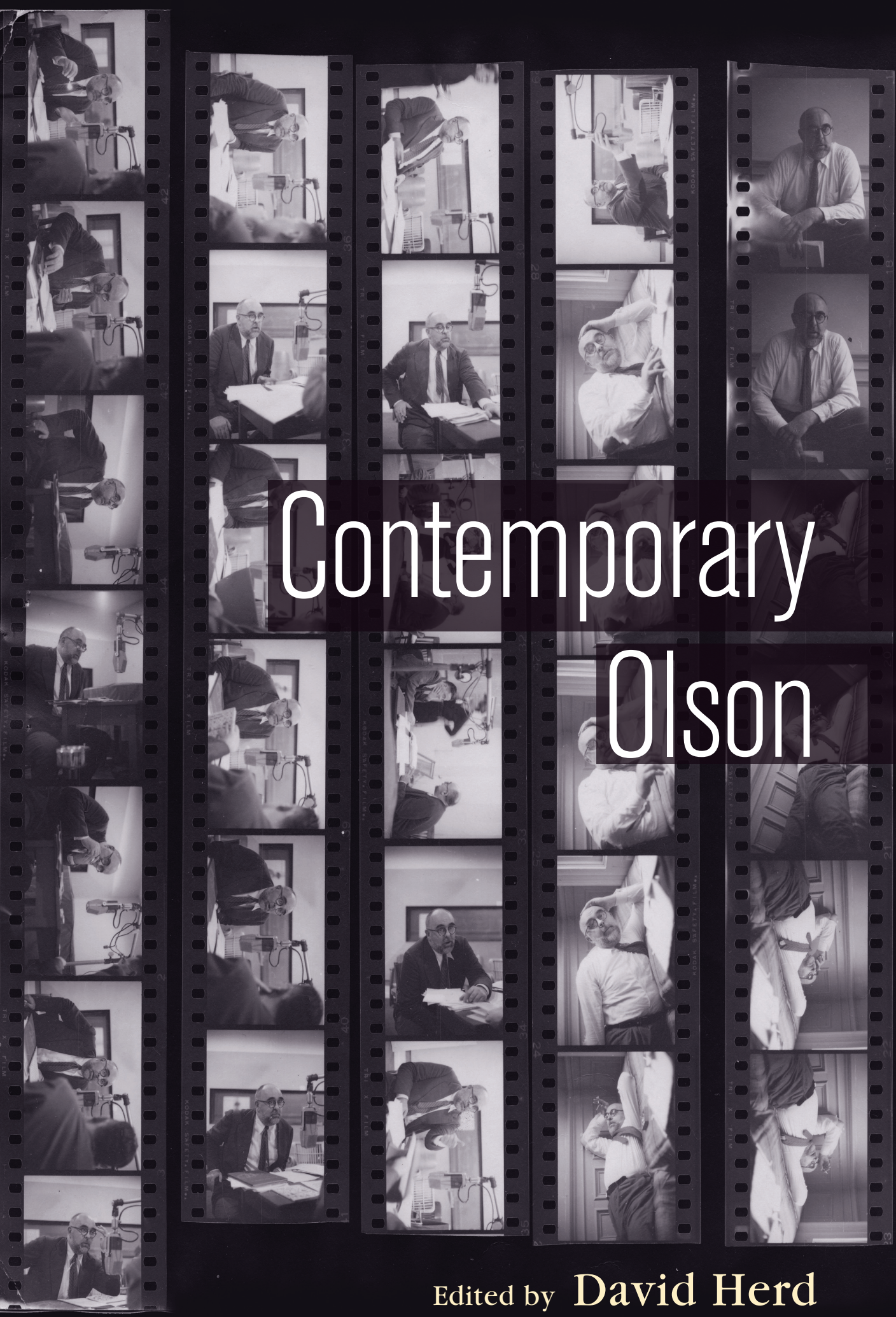




\section{Contemporary Olson}

\section{MANCHESTER 1824}

Manchester University Press 
David Herd - 9781526110794 Downloaded from manchesterhive.com at $04 / 26 / 2023$ 03:25:48PM via free access 


\title{
Contemporary Olson
}

\author{
edited by \\ DAVID HERD
}

Manchester University Press 


\section{Copyright (C) Manchester University Press 2015}

While copyright in the volume as a whole is vested in Manchester University Press, copyright in individual chapters belongs to their respective authors, and no chapter may be reproduced wholly or in part without the express permission in writing of both author and publisher.

Published by Manchester University Press Altrincham Street, Manchester M1 7JA, UK www.manchesteruniversitypress.co.uk

British Library Cataloguing-in-Publication Data A catalogue record for this book is available from the British Library Library of Congress Cataloging-in-Publication Data applied for ISBN 9780719089718 hardback

First published 2015

The publisher has no responsibility for the persistence or accuracy of URLs for external or any third-party internet websites referred to in this book, and does not guarantee that any content on such websites is, or will remain, accurate or appropriate.

Typeset in Sabon by Koinonia, Manchester 